\title{
PREDIKTOR KESULITAN MEMBACA PERMULAAN DI SEKOLAH DASAR
}

\author{
Mohammad Arif Taboer ${ }^{1}$ \\ Endang Rochyadi ${ }^{2}$ \\ Sunardi $^{2}$ \\ Bahrudin $^{1}$ \\ ${ }^{1}$ Prodi Pendidikan Khusus, Fakultas Ilmu Pendidikan, Universitas Negeri Jakarta \\ ${ }^{1}$ Jl. R. Mangun Muka Raya, RT.11/RW.14, Rawamangun, Jakarta, Indonesia \\ ${ }^{2}$ Prodi Pendidikan Khusus, Universitas Pendidikan Indonesia \\ ${ }^{2}$ Jl. Dr. Setiabudi No.229, Bandung, Jawa Barat, Indonesia \\ *e-mail: arif.taboer@unj.ac.id
}

Artikel diterima: 13 November 2020; disetujui: 5 Desember 2020

\begin{abstract}
This article is intended to describe predictors of initial reading difficulty in students with reading difficulties in primary schools. This study used a descriptive research design. The results of this study indicate that the predictors that cause reading difficulties in students are (1) phonological awareness, (2) visual perception, and (3) one predictor that is still uncertain. However, the interesting thing is the phenomenon where students do not experience obstacles in phonological awareness or visual perception, but still experience difficulties in reading. The presumptions that appear in the last predictor are related to external factors.
\end{abstract}

Keywords: Initial reading difficulties; students with reading difficulties; predictors of initial reading difficulties

\begin{abstract}
Abstrak: Artikel ini ditujukan guna mendeskripsikan prediktor kesulitan membaca permulaan pada siswa dengan kesulitan membaca di sekolah dasar. Penelitian ini menggunakan rancangan penelitian deskriptif. Hasil penelitian ini menunjukan bahwa prediktor yang menyebabkan kesulitan membaca pada siswa adalah (1) kesadaran fonologi, (2) persepsi visual, dan (3) satu prediktor yang masih belum diketahui secara pasti. Namun demikian hal yang menarik adalah fenomena dimana para siswa tidak mengalami hambatan dalam kesadaran fonologi ataupun persepsi visual, namun masih tetap mengalami kesulitan dalam membaca. Dugaan yang muncul pada prediktor terakhir adalah berkenaan dengan faktor eksternal.
\end{abstract}

Kata kunci: Kesulitan membaca permulaan; siswa dengan kesulitan membaca; prediktor kesulitan membaca permulaan

\section{PENDAHULUAN}

Keterampilan membaca bukanlah suatu hal yang dapat berkembang secara alamiah layaknyanya perkembangan bahasa. Tidak diragukan lagi bahwa perkembangan manusia sangat bergantung dari pengalaman belajar yang distimulasikan oleh lingkungan. Namun demikian dalam 
perkembangan membaca yang dimulai dari membaca permulaan perkembangan keterampilan ini perlu dilakukan sebuah proses perencanaan yang sistematis tidak seperti perkembangan bahasa. Perkembangan sistemasi yang dimaksud adalah perkembangan yang direncanakan layaknya sebuah pembelajaran. Oleh sebab itu kita sering jumpai adanya orang dewasa yang belum dapat membaca. Hal ini dimungkinkan karena pengalaman belajar membaca tidak direncanakan secara sistematis.

Membaca permulaan merupakan proses memecahkan simbol-simbol orthography ke dalam kode-kode bunyi ujar bahasa (Lyster, 1998). Kesulitan membaca permulaan diartikan sebagai sebuah kondisi dimana individu mengalami kesulitan atau hambatan dalam memecahkan simbolsimbol orthography ke dalam kode-kode bunyi ujar. Inti dari kesulitan membaca permulaan adalah bagaimana seseorang dapat memecahkan simbol-simbol orthography menjadi bunyi-bunyi bahasa yang dipahaminya. Dengan demikian mereka yang mengalami kesulitan membaca akan mengalami kesulitan membaca suatu kata. Rangkaian huruf-huruf yang tersusun dalam sebuah kata akan sulit "dibunyikan" dalam bahasa yang dipahaminya.

Bentuk kesulitan membaca yang ditunjukkan adalah kesulitan dalam mengeja, penghilangan huruf, penyisipan huruf, pembalikan huruf dan salah dalam mengucapkan huruf (Masroza, 2013). Dalam hasil penelitian yang lain ditemukan bahwa kesulitan membaca permulaan ditunjukkan oleh siswa melalui kesulitan dalam pengenalan huruf dan merangkai huruf menjadi suku kata serta suku kata menjadi kata (Muhyidin, 2016). Bentuk kesulitan membaca permulaan dalam penelitian berikutnya meliputi kesulitan mengidentifikasi huruf dan merangkai susunan huruf, membalik huruf, mengubah kata, menghilangkan huruf dalam susunan kata, mengeja terbata-bata, mengucapkan kata salah (Rizkiana, 2016).

Kesulitan membaca permulaan diawali dengan keyakinan bahwa hal ini berkaitan dengan IQ. Namun demikian sejalan dengan waktu IQ ternyata tidak mempangaruhi keterampilan membaca permulaan seseorang (Orlovska dkk., 2014; Stanovich, 2005). Selanjutnya, ditemukan bahwa individu dengan hambatan pendengaran teridentifikasi dapat melakukan aktivitas membaca permulaan (Andrews dkk., 2016). Walaupun aktivitas membaca merupakan budaya orang-orang mendengar, namun demikian penelitian tersebut membuktikan bahwa individu dengan hambatan pendengaran membangun cara tersendiri untuk dapat membaca. Dengan demikian temuan-temuan yang telah dipaparkan membuktikan bahwa keyakinan mengenai keterampilan membaca permulaan dapat dipengaruhi oleh IQ dan kondisi hambatan pendengaran pada akhirnya dapat menjadi masa lalu. Pertanyaan yang muncul adalah apa yang menjadi prediktor dalam fenomena kesulitan membaca di sekolah dasar?

Kesadaran fonologi yang rendah merupakan prediktor terkuat bagi munculnya kesulitan dalam membaca. Kesadaran fonologi merupakan kesadaran seseorang dalam memahami 
segmentasi bunyi ujar dalam pembentukan sebuah kata (Trehearne dkk., 2003). Jika dihubungkan dalam konteks Bahasa Indonesia maka kesadaran fonologi merupakan kesadaran seseorang dalam memahami segmentasi dalam sebuah kata yang diujarkan dalam bentuk suku kata dan fonem.

Komponen kesadaran fonologis pada dasarnya terbagi atas 3 bagian, yakni faktor fonem, faktor suku kata dan faktor rima (Høien dkk., 1995). Faktor fonem merupakan kesadaran seseorang dalam mengidentifikasi bunyi fonem yang terdapat didalam sebuah kata. Kasadaran ini dapat dilihat pada mengidentifikasi fonem awal dan akhir; manipulasi fonem pada kata. Faktor suku kata meliputi menghitung suku kata; mengidentifikasi suku kata awal dan akhir. Faktor rima meliputi mengidentifikasi rima pada awal dan akhir kata baik dalam segi fonem maupun suku kata. Komponen-komponen tersebut merupakan varian dari kemungkinan hambatan yang terjadi pada siswa yang mengalami kesulitan dalam kesadaran fonologis.

Persepsi visual diterjemahkan sebagai kemampuan seseorang dalam memahami apa yang dilihat (Bos \& Vaughn, 2002). Kemampuan memahami melibatkan proses melihat, memperhatikan, menyimpulkan serta menyimpan hasil ingatan. Ingatan penglihatan yang dipahami merupakan hasil penglihatan secara detai sehingga menemukan ciri-ciri khas dari objek yang dilihatnya. Keterlibatan persepsi visual dengan membaca telah banyak di selidiki oleh banyak peneliti. Hasilnya ditemukan adanya hubungan persepsi visual dengan kemampuan membaca (English, 1981; Garje Mona dkk., 2015; Lyster, 1998; Rochyadi, 2011; Safaei dkk., 2014; Spache, 1964). Namun demikian hubungan antara persepsi visual tidak sekuat kesadaran linguistik (Rochyadi, 2011).

Dalam proses membaca, kontak pertama antara pembaca dengan bacaan adalah melalui kontak antara visual dengan teks. Pembaca akan memusatkan perhatiannya pada teks bacaan (English, 1981). Teks bacaan kemudian diterjemahkan secara visual. Dalam proses ini melibatkan tiga hukum visual dalam membaca. Pertama adalah object constancy. Dalam hal ini objek adalah sama tanpa harus memparhatikan posisi. Kedua, directionality. Dalam hal ini ciri sebuah objek mempunyai kesamaan arah, seperti "b" akan menjadi "b" jika arahnya sama. Bukan seperti "b" menjadi "d". Ketiga adalah formed constancy. Dalam hal ini kesamaan objek dalam bentuk ukuran, seperti "c" ada dalam bentuk kapital dan ada yang kecil.

Persoalan yang muncul dalam persepsi visual dalam membaca permulaan terletak pada persoalan fungsi kognisi visual (Juhanaini \& Susilawati, 2009; Taboer dkk., 2019). Hal ini disebabkan persoalan fungsi kognisi visual banyak terlibat dalam proses memahami apa yang dilihat. Untuk dapat memahami apa yang dilihat maka dibutuhkan 1) perhatian visual, 2) diskriminasi visual, dan 3) ingatan visual.

Paparan di atas menunjukkan bahwa dalam terdapat beberapa aspek yang mempengaruhi kemampuan individu dalam membaca. Dalam membaca permulaan di sekolah dasar, dapat 
ditemukan siswa yang masih mengalami kesulitan dalam membaca. Kesulitan ini dapat diatasi dengan menemukan prediktor penyebab kesulitan tersebut. Dengan demikian, diperlukan analisis lebih lanjut untuk mengungkap prediktor khususnya pada siswa sekolah dasar yang mengalami kesulitan dalam membaca permulaan.

\section{METODE}

Penelitian ini didasarkan pada kasus masalah membaca permulaan yang dialami oleh 7 sekolah dasar di wilayah Jakarta Timur pada tahun 2018. Kesimpulan dari penelitian ini bukan untuk membuat generalisasi akan tetapi mendeskripsikan prediktor dari kesulitan membaca yang dialami oleh siswa di sekolah dasar. Pemilihan sekolah didasarkan pada keterjangkauan akses untuk melakukan penelitian, waktu dan lokasi (Creswell \& Poth, 2016). Semua siswa yang mengalami masalah membaca di sekolah menjadi responden. Total ditemukan 26 siswa yang mengalami masalah dalam membaca.

Instrumen yang digunakan dalam mengumpulkan data adalah tes. Tes yang digunakan adalah tes informal. Validitas yang digunakan dalam tes ini adalah validitas konstruk. Berdasarkan hal tersebut, proses validasi dilakukan melalui pemeriksaan para ahli lexpert judgement. Ada 4 jenis instrumen tes yang yang digunakan dalam menemukan prediktor kesulitan membaca yang terjadi pada siswa. Tes tersebut adalah, 1) tes kesadaran fonologis, 2) tes persepsi visual, 3) tes identifikasi huruf dan suku kata, dan 4) membaca kata dan kalimat sederhana. Analisis data dilakukan melalui tabulasi.
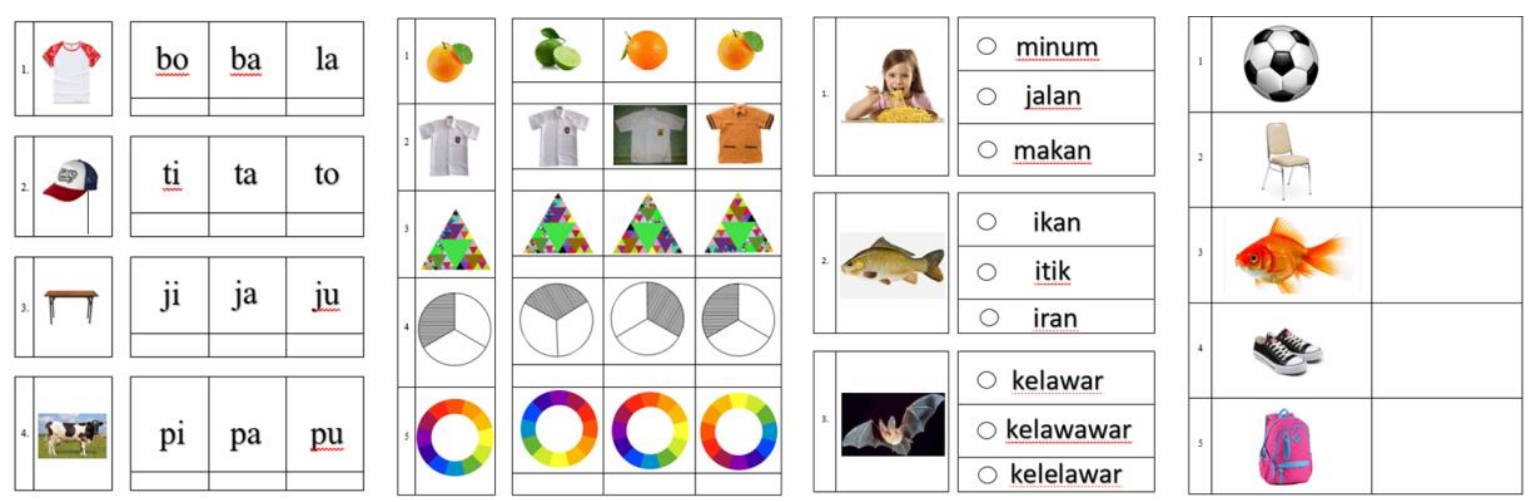

Gambar 1. Contoh Instrumen Tes yang Digunakan

\section{HASIL DAN PEMBAHASAN}

Data pada penelitian ini diperoleh berdasarkan hasil tes tes kesadaran fonologis; tes persepsi visual; tes identifikasi huruf dan suku kata; dan membaca kata dan kalimat sederhana. Data yang diperoleh melalui hasil tes dari 26 siswa dipaparkan pada Tabel 1. Data pada Tabel 1 menunjukan bahwa para peserta mempunyai skor kesadaran fonologi diatas 70 sebanyak 10 orang atau sebanyak $38,46 \%$ siswa mengalami kesulitan dalam kesadaran fonologi. Siswa yang mempunyai 
skor diatas 74 pada kemampuan persepsi visual sebanyak 9 orang atau sebanyak $34 \%$ siswa yang mengalami kesulitan dalam persepsi visual.

Selanjutnya ditemukan sebanyak 6 orang siswa atau sebanyak 23\% siswa mempunyai skor kesadaran fonologi dan persepsi visual diatas batas lulus ideal. Berikutnya terdapat 5 orang siswa atau sebanyak 19,23\% siswa mempunyai rata-rata nilai yang sedikit di bawah batas ideal akan tetapi mempunyai keterampilan membaca atau decoding kata dengan skor yang di bawah penilaian acuan patokan dalam membaca atau decoding kata, yakni $80 \%$.

Tabel 1. Sebaran Kemampuan Membaca Permulaan Siswa dengan Kesulitan Membaca di Sekolah Dasar

\begin{tabular}{cllcccc}
\hline & & & & & \multicolumn{2}{c}{ Dekoding } \\
\cline { 5 - 6 } & Nama & Kelas & $\begin{array}{c}\text { Kesadaran } \\
\text { Fonologi }\end{array}$ & Persepsi Visual & Huruf dan Suku & Kata \\
\hline 1 & b & III & 95,00 & 70,00 & 53,96 & 36,67 \\
2 & c & III & 93,75 & 86,67 & 45,44 & 23,33 \\
3 & e & III & 71,25 & 86,67 & 64,00 & 43,33 \\
4 & f & II & 80,00 & 100,00 & 65,59 & 34,33 \\
5 & h & II & 52,50 & 60,00 & 50,23 & 36,67 \\
6 & i & II & 53,75 & 83,33 & 44,65 & 20,00 \\
7 & j & III & 50,00 & 80,00 & 58,34 & 20,00 \\
8 & k & III & 41,25 & 96,67 & 60,10 & 43,67 \\
9 & l & II & 73,75 & 50,00 & 65,63 & 43,33 \\
10 & m & II & 65,00 & 63,33 & 49,88 & 26,67 \\
11 & n & II & 57,50 & 50,00 & 53,70 & 40,00 \\
12 & o & II & 80,00 & 50,00 & 27,34 & 26,67 \\
13 & q & II & 63,75 & 60,00 & 69,79 & 46,67 \\
14 & r & II & 56,25 & 33,33 & 47,88 & 40,00 \\
15 & s & IV & 71,25 & 63,33 & 54,44 & 23,33 \\
16 & t & IV & 17,50 & 40,00 & 13,33 & 0,00 \\
17 & v & II & 62,50 & 60,00 & 70,57 & 40,00 \\
18 & w & II & 57,50 & 33,33 & 62,20 & 46,67 \\
19 & x & II & 41,25 & 43,33 & 64,85 & 50,00 \\
20 & y & II & 83,75 & 73,33 & 74,54 & 43,33 \\
21 & z & II & 66,25 & 66,67 & 65,38 & 33,33 \\
22 & aa & II & 70,00 & 70,00 & 45,63 & 40,00 \\
23 & bb & III & 73,75 & 80,00 & 57,78 & 36,67 \\
24 & cc & IV & 71,25 & 100,00 & 49,63 & 10,00 \\
25 & dd & III & 67,50 & 86,67 & 57,78 & 10,00 \\
26 & ee & V & 50,00 & 83,33 & 59,16 & 31,00 \\
\hline & & & & & \\
\end{tabular}

Membaca merupakan keterampilan yang dimiliki oleh manusia melalui sebuah proses pembelajar yang disusun secara sistematis. Membaca bukanlah keterampilan yang secara alamiah 
berkembang dalam diri manusia (Liberman, 1992; Lyon, 1998; Orlovska dkk., 2014). Jika memang keterampilan membaca merupakan hasil intervensi maka lingkungan sosial menjadi faktor yang turut menjadi faktor yang patut diperhitungkan. Hal ini disebabkan faktor lingkungan khususnya lingkungan sosial terdekat dengan siswa. Orang tua, guru dan teman sebaya merupakan individu yang berada pada lingkungan mikrosistem (Vélez-Agosto dkk., 2017). Lingkungan sosial yang sangat mengetahui mengenai membaca permulaan adalah guru. Selanjutnya, Lingkungan sosial ini dipengaruhi oleh norma (Vélez-Agosto dkk., 2017). Norma atau aturan-aturan yang berisikan mengenai membaca permulaan adalah kurikulum. Dengan demikian guru dan kurikulum merupakan bagian dalam berkembangnya keterampilan membaca pada siswa. Walsh dkk. (2006) mengemukakan bahwa "children fail to learn to read in school because they aren't being taught correctly".

Pengetahuan guru tentang substansi materi dan metode pembelajaran merupakan hal penting yang harus dimiliki sebelum proses belajar mengajar dilaksanakan. Kedua hal inilah yang menjadi salah satu prediktor keberhasilan belajar siswa. Pengetahuan guru tentang mata pelajaran yang diajarkan berkaitan erat dengan perolehan kemampuan siswa (Nor dkk., 2019). Hal ini juga menunjukkan bahwa guru yang memiliki pengetahuan tentang apa yang diajarkan sangat erat hubungannya dengan pencapaian kemampuan siswa (Fauziah, 2011; Sulfemi, 2019).

Aksara Bahasa Indonesia memiliki cerita yang panjang. Semua aksara yang ada di Indonesia pada masa lalu berbeda dengan aksara yang digunakan saat ini (Roza, 2017). Informasi ini menjelaskan bahwa secara alamiah aksara Indonesia adalah huruf-huruf dengan karakter pembantu karena kata dalam Bahasa Indonesia dibentuk berdasarkan suku kata. Dari sejarah, kita belajar bahwa seharusnya ada pembedaan pengajaran membaca dalam Bahasa Indonesia dan Bahasa Inggris. Hal ini perlu diketahui oleh semua guru yang mengajar membaca, karena hasil penelitian ini menunjukkan bahwa $80 \%$ siswa mengalami kesulitan dalam membaca karena decoding kata.

Unsur pembentuk kata dalam Bahasa Indonesia adalah suku kata (Resticka, 2017). Pola suku kata asli dalam bahasa Indonesia adalah Vokal (V), Konsonan-Vokal (KV), dan Konsonan-VokalKonsonan (KVK) (Alwi dkk., 2019). Pada sisi lain, pembelajaran membaca permulaan adalah dengan menggunakan metode bunyi dan abjad (Muhyidin, 2016). Fenomena ini menunjukan kecenderungan ada suatu hal yang perlu dikaji lebih mendalam mengenai pembelajaran membaca permulaan. Apakah guru memahami perkembangan metode ataupun teknik pembelajaran membaca permulaan? Apakah keseluruhan ini terfasilitasi di dalam kurikulum 2013?

Kesadaran fonologi merupakan prediktor terkuat bagi seseorang mengalami kesulitan dalam membaca (Piquard-Kipffer \& Sprenger-Charolles, 2013; Stanovich, 2005). Kesadaran fonologi adalah kemampuan seseorang terhadap bunyi-bunyi yang membentuk kata yang diucapkan. Kesadaran ini dibutuhkan guna menghubungkan antara fonem dengan grafem. Kesadaran fonologi 
harus diberikan kesempatan dipelajari anak semenjak anak belajar di taman kanak-kanak (Ayriza, 1997; Lyster, 1998). Hal yang menjadi pertanyaan adalah apakah kurikulum dan guru telah memberikan kesempatan pada anak-anak mengembangkan kesadaran fonologinya? Selanjutnya, apakah pada kurikulum sekolah dasar, para siswa telah diberikan kesempatan belajar membaca permulaan seperti selayaknya orang berbahasa Indonesia belajar membaca? Pertanyaan-pertanyaan ini perlu dijawab pada penelitian selanjutnya untuk mengungkap faktor pembelajaran di sekolah dasar yang melandasi kesadaran fonologi.

Pada akhirnya fenomena lain yang perlu dilihat dalam memahami kesulitan membaca permulaan adalah fenomena lingkungan sosial. Lingkungan sosial terdekat dengan siswa dengan kesulitan membaca merupakan hal yang mempengaruhi perkembangan siswa itu sendiri (VélezAgosto dkk., 2017). Terdapat hubungan antara lingkungan sosial dengan komponen membaca (Piquard-Kipffer \& Sprenger-Charolles, 2013). Dengan demikian jelaslah bahwa membaca permulaan merupakan keterampilan yang dibangun melalui sebuah proses yang sistematis. Lingkungan sosial di sekolah merupakan lingkungan sosial yang sangat menentukan dalam hal ini, karena pemahaman mengenai membaca permulaan baik secara teoritikal dan praktikal ada pada guru.

\section{SIMPULAN DAN SARAN}

\section{Simpulan}

Siswa yang mengalami kesulitan membaca pada akhirnya ditemukan mempunyai kesadaran fonologi ataupun persepsi visual yang rendah. Prediktor tersebut dapat terjadi bersamaan atau secara tunggal. Namun demikian hal yang menarik adalah fenomena dimana para siswa tidak mengalami hambatan dalam kesadaran fonologi ataupun persepsi visual namun masih tetap mengalami kesulitan dalam membaca. Hasil dan pembahasan menunjukan bahwa selain factor kesadaran fonologis dan persepsi visual, tidak menutup kemungkinan faktor eksternal menjadi prediktor berikutnya.

\section{Saran}

Berdasarkan hal inilah sangat diperlukan penelitian lanjutan untuk mengungkap prediktor lain yang menyebabkan siswa mengalami kesulitan dalam membaca permulaan. Penggalian informasi mengenai kompetensi para guru dalam mengajarkan membaca permulaan dan analisis kurikulum sangat perlu dilakukan guna memahami fenomena ini.

\section{DAFTAR RUJUKAN}

Alwi, H., Dardjowidjojo, S., Lapoliwa, H., \& Moeliono, A. M. (2019). Tata Bahasa Baku Bahasa Indonesia. 
Andrews, J. F., Hamilton, B., Dunn, K. M., \& Clark, M. D. (2016). Early Reading for Young Deaf and Hard of Hearing Children: Alternative Frameworks. Psychology, 7(4). https://doi.org/10.4236/psych.2016.74052

Ayriza, Y. (1997). Pelatihan Kesadaran Fonologis Pada Anak-anak Prasekolah untuk Menyambut Tugas Belajar Membaca Pada Masa Sekolah. Cakrawala Pendidikan, 86829.

Bos, C. S., \& Vaughn, S. (2002). Strategies for Teaching Students with Learning and Behavior Problems. ERIC.

Creswell, J. W., \& Poth, C. N. (2016). Qualitative Inquiry and Research Design: Choosing Among Five Approaches. Sage publications.

English, K. P. (1981). Visual Perception and Reading Disabilities. Australian Journal of Opthalmology, 9(3), 181-184.

Fauziah, Y. N. (2011). Analisis Kemampuan Guru dalam Mengembangkan Keterampilan Berpikir Kreatif Siswa Sekolah Dasar kelas V pada Pembelajaran Ilmu Pengetahuan Alam. Jurnal Edisi Khusus, 1(1), 98-106.

Garje Mona, P., Dhadwad, V., Yeradkar, M. R., Adhikari, A., \& Setia, M. (2015). Study of Visual Perceptual Problems in Children with Learning Disability. Indian Journal of Basic and Applied Medical Research, 4(3), 492-97.

Høien, T., Lundberg, I., Stanovich, K. E., \& Bjaalid, I.-K. (1995). Components of Phonological Awareness. Reading and writing, 7(2), 171-188.

Juhanaini, J., \& Susilawati, E. (2009). Pengaruh Latihan Kesadaran Persepsi Visual terhadap Kemampuan Membaca Permulaan pada Anak Tunagrahita Ringan di SLB Kasih Ibu dan SLB YJS III Kabupaten Bandung. JASSI ANAKKU, 8(1), 49-53.

Liberman, A. M. (1992). The Relation of Speech to Reading and Writing. Dalam Advances in psychology (Vol. 94, hlm. 167-178). Elsevier.

Lyon, G. R. (1998). Why Reading is not a Natural Process. Educational leadership, 55(6), 14-18.

Lyster, S.-A. H. (1998). Preventing Reading Failure: A Follow-Up Study. Dyslexia, 4(3), 132-144.

Masroza, F. (2013). Prevalensi Anak Berkesulitan Belajar di Sekolah Dasar se Kecamatan Pauh Padang. Jurnal Ilmiah Pendidikan Khusus, 1(1), 215-227.

Muhyidin, A. (2016). Pembelajaran Membaca dan Menulis Permulaan Bahasa Indonesia di Kelas Awal. BAHTERA: Jurnal Pendidikan Bahasa dan Sastra, 15(2), 1-13.

Nor, N. M., Embong, R., Muda, H., Yunus, K., \& Nor, J. M. (2019). Effects of Teachers' Teaching Competencies on Students' Academic Performance Mediated by Holistic Centered Learning Style Based on SUMUR Program at Secondary Religious Schools. International Journal of Academic Research in Progressive Education and Development, $8(2), 25-38$.

Orlovska, M., Bluss, K., \& Rascevska, M. (2014). The Relationship Between Children'S Reading Ability, Verbal and Fluid Intelligence and Measurements of Eye Movements During Reading. SHS Web of Conferences, 10, 00030. https://doi.org/10.1051/shsconf/20141000030

Piquard-Kipffer, A., \& Sprenger-Charolles, L. (2013). Early Predictors of Future Reading Skills: A follow-up of French-speaking Children from the Beginning of Kindergarten to the end of the Second Grade (age 5 to 8). LAnnee psychologique, 113(4), 491-521.

Resticka, G. A. (2017). Interferensi Morfologi Bahasa Indonesia ke dalam Pemakaian Bahasa Jawa di Media Massa. Jurnal Ilmiah Lingua Idea, 6(2), 70-85.

Rizkiana, R. (2016). Analisis Kesulitan Membaca Permulaan Siswa Kelas I SD N Bangunrejo 2 Yogyakarta. BASIC EDUCATION, 5(34), 3-236. 
Rochyadi, E. (2011). Model Pembelajaran Berbasis Kesadaran Linguistik dan Kemampuan Persepsi Visual Untuk Meningkatkan Kemampuan Membaca Anak Tunagrahita. Disertasi. Bandung: SPs UPI.

Roza, E. (2017). Aksara Arab-Melayu di Nusantara dan Sumbangsihnya dalam Pengembangan Khazanah Intelektual. TSAQAFAH, 13(1), 177-204.

Safaei, L., Bafrooee, K. B., \& Yarmohammadian, A. (2014). Effectiveness of Visual Perception Skills to Improve Reading Performance of Elementary Second Grade Students With Learning Disabilities. Indian Journal Science, 7(1), 269-274.

Spache, G. D. (1964). Ways of Defining the Reading Process. Reading in the Elementary School, 22-26.

Stanovich, K. E. (2005). The Future of a Mistake: Will Discrepancy Measurement Continue to Make the Learning Disabilities Field a Pseudoscience? Learning Disability Quarterly, 28(2), 103-106.

Sulfemi, W. B. (2019). Kemampuan Pedagogik Guru.

Taboer, M. A., Kartadinata, S., \& Rochyadi, E. (2019). Assessing Students with Reading Problem in Elementary School: A Case Study in 7 Elementary Schools. 1st International Conference on Education Social Sciences and Humanities (ICESSHum 2019).

Trehearne, M., Healy, L. H., Cantalini, M., \& Moore, J. L. (2003). Comprehensive Literacy Resource for Kindergarten Teachers. ETA/Cuisenaire Vernon Hills, IL.

Vélez-Agosto, N. M., Soto-Crespo, J. G., Vizcarrondo-Oppenheimer, M., Vega-Molina, S., \& García Coll, C. (2017). Bronfenbrenner's Bioecological Theory Revision: Moving Culture from the Macro into the Micro. Perspectives on Psychological Science, 12(5), 900-910.

Walsh, K., Glaser, D., \& Wilcox, D. D. (2006). What Education Schools aren't Teaching About Reading and What Elementary Teachers aren't Learning. National Council on Teacher Quality. 